\title{
Effect of Tiger Nut Residue Flour Inclusion on the Baking Quality of Confectionaries
}

\author{
Eke-Ejiofor, J. ${ }^{1} \&$ Deedam, J. N. ${ }^{1}$ \\ ${ }^{1}$ Department of Food Science and Technology, Rivers State University of Science and Technology Nkpolu, \\ P.M.B. 5080, Port Harcourt \\ Correspondence: Eke-Ejiofor, J. Department of Food Science and Technology, Rivers State University of \\ Science and Technology Nkpolu, P.M.B. 5080, Port Harcourt, Nigeria. Tel: 234-703-311-7436. E-mail: \\ joyekee@yahoo.co.uk
}

Received: July 19, 2015 Accepted: August 6, 2015 Online Published: September 21, 2015

doi:10.5539/jfr.v4n5p172 URL: http://dx.doi.org/10.5539/jfr.v4n5p172

\begin{abstract}
Cakes and biscuits were prepared from blends of wheat and tiger nut residue flours produced using raw and dry extraction method and substituted at 5\%,10\%,15\% and 20\% levels. The cakes and biscuits were analyzed for proximate composition, physical characteristics and sensory properties. Results for proximate composition indicated that moisture, fibre, ash, protein and fat contents increased with an increase in tiger nut residue substitution. Ash content for cake increased from $0.93 \%$ in sample A ( $100 \%$ wheat flour) to $1.40 \%$ in sample E ( $80 \%$ wheat flour: $20 \%$ tiger nut residue flour), while ash for biscuit increased from $1.35 \%$ in sample A (100\% wheat flour) to $1.85 \%$ in sample B $(95 \%$ wheat flour: $5 \%$ tiger nut residue flour). Fibre content for cake increased from $1.08 \%$ in sample A (100\% wheat flour) to $3.15 \%$ in sample E ( $80 \%$ wheat flour: $20 \%$ tiger nut residue flour) as substitution increased, while for biscuit fibre increased from $1.59 \%$ in sample A (100\% wheat flour) to $3.13 \%$ in sample D (85\% wheat flour: $15 \%$ tiger nut residue flour). Moisture content for cake increased from $21.95 \%$ in sample A ( $100 \%$ wheat flour) to $28.49 \%$ in sample E ( $80 \%$ wheat flour: $20 \%$ tiger nut residue flour) while for biscuit moisture increased from $1.08 \%$ in sample A (100\% wheat flour) to $2.78 \%$ in sample B (95\% wheat flour: 5\% tiger nut residue flour). There was a statistical significant difference in all samples with increase in substitution. Result for physical characteristics showed a significant $(p \leq 0.05)$ increase in cake volume and spread ratio of biscuit with increase in level of substitution of tiger nut residue flour. Sensory evaluation result for cakes showed sample E ( $80 \%$ wheat flour: $20 \%$ tiger nut residue flour) as most acceptable for cakes, in terms of color (4.3), aroma (3.95), taste (4.2), texture (4.05) and general acceptability (4.3) while for biscuits sample B(95\% wheat flour:5\% tiger nut residue flour) as most acceptable in terms of color (4.15) aroma, (4.0) taste, (4.15) texture (4.3) and overall acceptability (4.35).
\end{abstract}

Keywords: utilization, tiger- nut, residue flour, cakes, biscuits

\section{Introduction}

Confectionery is related to food item that are rich in sugar and often referred to as a confection. It is the art of creating sugar based desert (Magee, 2009). Cake is an item of soft sweet food made from baking a mixture of flour, eggs and sugar. It is a form of bread or bread-like food served alone, as a desert amongst other food items or taking in a picnic (Ohl et al., 1981). Biscuit is a small, flat crispy cake. They are nutritive snacks produced from palatable dough that is transformed into appetizing product through the application of heat in an oven (Kure et al., 1998). Biscuits are a rich source of fat and carbohydrates, hence are energy giving food and also a good source of protein (Kure et al., 1998).

Tiger nut (Cyperus esculentus var sativa) a lesser known and underutilized crops, many of which are potentially valuable as human and animal food, has been identified to maintain a balance between population growth and agricultural productivity particularly in the tropical and sub-tropical areas of the world (Adejuyitan, 2011) with reference to Nigeria. It has been reported to be high in carbohydrate, moderate protein, oleic acid, mineral, vitamin C and E contents (Esteshola \& Oreadu, 1996; Omode et al., 2004). Tiger nut produces about 25\% oil of high quality and protein about $8 \%$ of the nut, where valued for their nutritious content, and dietary fibre. Tiger nut can be eaten raw, dried, roasted or grated and used as flour, vegetable milk, cosmetics, fuel, hog feed. It is 
pressed for its juice to make beverage called (chufa) which is equally obtained from the rhizome (Belewu \& Belewu, 2007). Tiger nut is found to be rich in myristic acid, oleic and linoleic acid (Eteshola \& Oraedu, 1996).

Flour is a powder which is made by grinding cereal grains, beans or other seeds or root like cassava. It is the main ingredient of bread, which is a staple food for many cultures. Wheat flour is generally the main ingredient for baked products world over, making the availability of the flour a major economic issue. Increase in population as well as increased consumption rate of wheat based products in Nigeria has posed a huge burden on the importation, utilization and cost of wheat based product. Tiger nut a lesser known and underutilized crop, which has been valued for its nutritious dietary fibre and carbohydrate content could be eaten raw, roasted, dried, baked or made into a refreshing drink with its residue discarded in most cases, thereby converting this ideal waste. It has also been reported that tiger nut with its inherent nutritional and therapeutic advantages could serve as good alternative to cassava in baking industry (Ade-Omowaye et al., 2008). Therefore the objectives of this study are to produce flour from tiger nut residue for value addition and to evaluate the effect of addition of tiger nut residue flour on the baking qualities of cakes and biscuits.

\section{Materials and Methods}

\subsection{Materials}

Tiger nuts (Cyperus esculentus) yellow variety used for this study was purchased from fruit garden market in Port Harcourt. Commercial wheat flour and other ingredients such as margarine, sugar, fresh eggs, salt, milk, flavor and sodium bicarbonate (baking powder) were purchased from Mile 1 market in Diobu, Port Harcourt. Rivers State, Nigeria.

\section{TIGER NUT SEED}

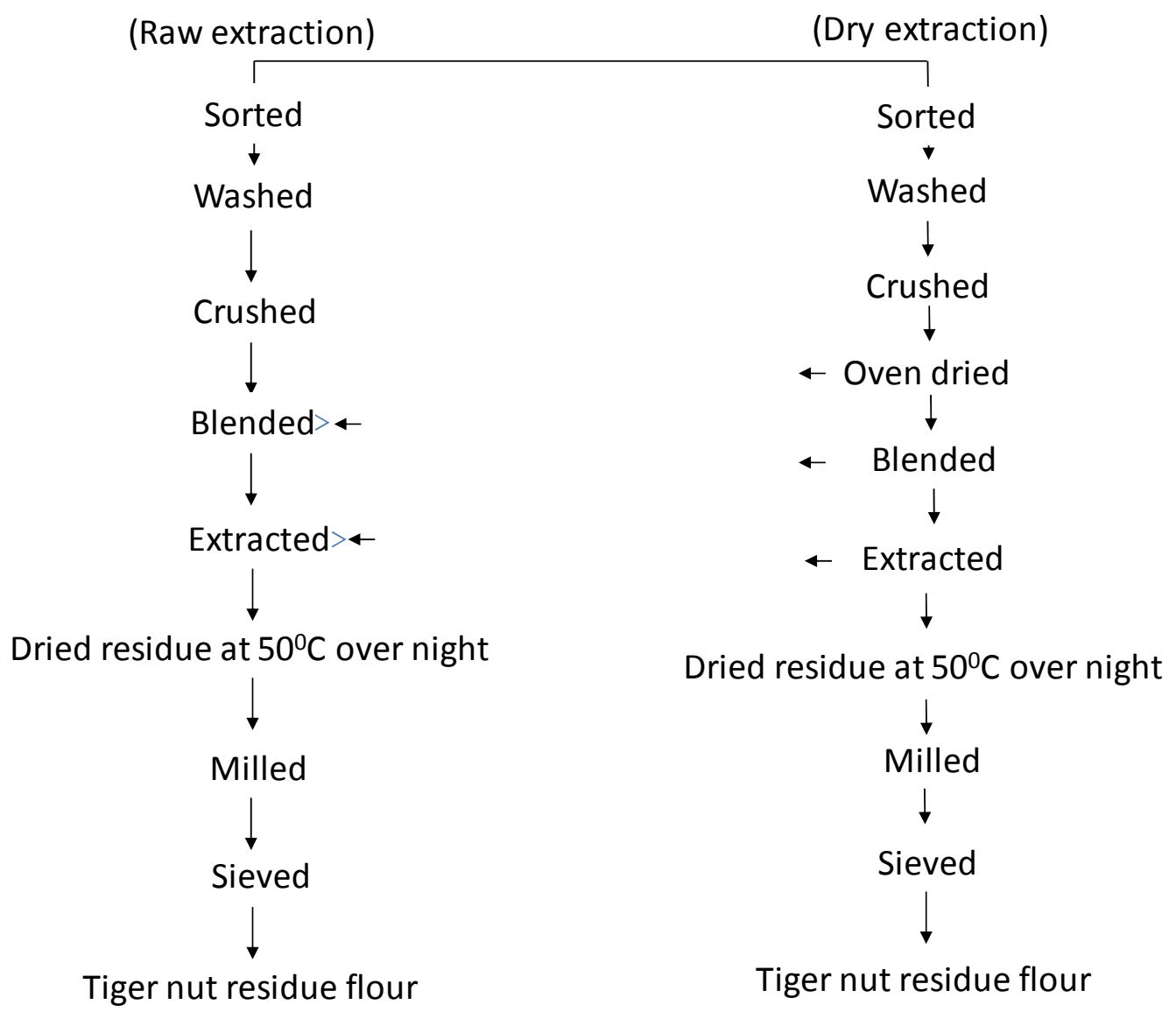

Figure 1. Flow chart illustrating the production of Raw and Dried tiger nut residue flour Source: Oladele and Aina (2007). 


\subsection{Preparation of Tiger Nut Residue Flour}

Tiger nut residue flour was prepared using two methods according to Figure 1. Seeds were sorted to remove defective seeds and carefully washed. Two kilograme freshly washed tiger nut seeds were divided into two (2) parts, the first part was crushed, blended and milk extracted leaving the residue, while the second part was crushed and oven dried at $50{ }^{\circ} \mathrm{C}$ for 24 hours before blending and extracting the milk before final drying. Dried tiger nut residues were milled into flour in a dry milling machine, cyclotec 1093 model, manufactured in Sweden by FOSS and sieved through a $50 \mathrm{~mm}$ laboratory sieve to obtain flour of uniform particular size. The flour was then stored in a plastic air-tight container with lid at room temperature $\left(37^{\circ} \mathrm{C}\right)$ for further analysis and preparation of cakes and biscuits.

\subsection{Wheat/Tiger Nut Composite Flour}

Seven blends of both raw and dry extracted tiger nut residue flour were prepared by mixing varying proportions of tiger nut residue flour with wheat flour. Flour ratios of 5, 10, and $15 \%$ for biscuit and up to $20 \%$ for cake, were used for baking.

\subsection{Recipe for Cake and Biscuit Production}

Flour $200 \mathrm{~g}$, margarine $125 \mathrm{~g}$, sugar $50 \mathrm{~g}$, salt $0.02 \mathrm{~g}$, baking powder $2 \mathrm{~g}$, egg for cake 3 , milk $75 \mathrm{ml}, 15 \mathrm{ml}$ water.

\subsection{Preparation of Products}

Cake was prepared using the creaming method as described by Victor et al. (1995) while biscuit was prepared by the rubbing-in- method as described by Oyewole et al. (1996).

\subsection{Sensory Evaluation}

Cake and biscuit samples were subjected to sensory evaluation within 24 hours of production. The following attributes namely, appearance, aroma, taste, texture and overall acceptability were assessed on cakes and biscuits samples, respectively using a 5 point hedonic scale with 5 as like extremely and 1 as dislike extremely. Twenty (20) trained panelists familiar with cake and biscuit, who were not hungry, neither sick nor allergic to baked products, were involved in the assessment. The panelists were instructed to rinse their month with water after tasting each cake or biscuit sample. Evaluation was done between 9-11am.

\subsection{Statistical Analysis}

Results were analyzed statistically using analysis of variance (ANOVA) and means were separated by least significant different (LSD) procedure, using the statistical package for social sciences (SPSS) version 20.0 soft ware 2007

\subsection{Chemical Analysis of Cake and Biscuit}

Chemical analysis of the samples such as moisture, ash, fat and protein were determined using the AOAC method (1990). While total available carbohydrate (TAC) was determined by the method described by Osborne and Voogt (1978) and fibre calculated by difference of moisture, ash, fat, protein and carbohydrate.

\subsection{Determination of Spread Ratio}

The spread ratio of biscuit sample was calculated using the formula below, as described by Oyewole et al. (1996):

$$
\text { Spread ratio }=\frac{\text { Diameter }}{\text { Height }}
$$

\subsection{Determination of Cake Volume}

Cake volume of samples were calculated using the formula below as described by Oyewole et al. (1996):

$$
V=1 / 3 n r 2_{h}
$$

Where $r$ radius, $h=$ height .

\section{Results and Discussion}

\subsection{Proximate Composition of Cakes from Wheat/Tiger Nut (Raw/Dry) Residue Composite Flour}

Table 1 shows the proximate composition of cakes from wheat/tiger nut (raw and dry) residue flour. Moisture content ranged from $21.95 \%-28.49 \%$ for the raw and $21.95 \%-24.82 \%$ for the dry residue flour cakes respectively, with sample A (100\% WF-Wheat flour) having the lowest and sample E (80\%WF: 20\% TNRFTiger nut residue flour) the highest in both cases. This result of the present study is higher than the findings of 
Eke-Ejiofor (2013) who reported a moisture content of $21.97 \%-22.26 \%$ for cake produced from African breadfruit/sweet potato-wheat composite flour blend with sample E showing the highest moisture content, which may be attributed to the increase in the addition of raw tiger nut residue flour. The study showed that the processing method used for the production of the flour affected the moisture content of the samples with the dry extracted tiger nut residue flour cake having the lowest moisture, indicating better keeping quality of the sample.

Ash content ranged from $0.72 \%-1.45 \%$ for the raw extracted flour and $0.82 \%-1.06 \%$ for the dry tiger nut residue flour, with sample B $(95 \% \mathrm{WF}$ and $5 \% \mathrm{TNRF})$ having the lowest in both cases and samples D (85\%WF:15\% TNRF) and E (80\%WF:20\% TNRF) as highest for raw and dry tiger nut residue flour respectively. Ash content for raw residue cake ranging from $0.72 \%$ to $1.45 \%$ agrees with the findings of Salve et al. (2011) with a value of $1.40 \%$. While for dry residue flour cake, ash content ranging from $0.82 \%$ to $1.06 \%$ is lower than the findings of Ajani et al. (2012) with a value of 1.43\%. Eke-Ejiofor (2013), reported ash values of 2.12-2.25\% for cake produced from African breadfruit/sweet potato-wheat composition flour blend. The result of this study showed that ash content increased with an increase in substitution level.

Protein content of cake ranged from $8.53 \%-10.38 \%$ in the raw residue flour, with sample C (90\%WF: $10 \%$ TNRF) as the lowest and samples $\mathrm{A}$ and $\mathrm{E}$ as the highest, while cakes from dry extracted residue flour had protein ranging from $8.69 \%-10.44 \%$ with sample D (85\%WF: $15 \% \mathrm{TNRF})$ having the lowest and sample $\mathrm{B}$ having the highest $(95 \% \mathrm{WF}$ and $5 \% \mathrm{TNRF})$. Protein content of the raw and dry residues in the present study are higher than the findings of Oderinde and Tahir (1988) with a value of 7\%, Akobundu et al. (1998) with a value of $9.51 \%$ and Eke-Ejiofor (2013) with a value of 5.78- 7.34\% for African breadfruit/sweet potato-wheat composite flour blends. Protein content decreased with increase in substitution of tiger nut residue flour. This may be as a result of the increase observed in carbohydrate and fiber as substitution level increased.

Fat content of cakes ranged from $18.81 \%-21.68 \%$ in the raw residue with sample C (90\%WF: $10 \% \mathrm{TNRF})$ having the lowest and $17.03 \%-24.62 \%$ in the dry residue with sample D (85\%WF: $15 \% \mathrm{TNRF}$ ) having the lowest and sample E ( $80 \%$ WF: $20 \%$ TNRF) having the highest in both cases. Fat content for raw extracted tiger nut residue cake ranging from $18.82 \%$ to $21.68 \%$, falls below the findings of Eke-Ejiofor (2013) with a value of $18.93-21.79 \%$ for African breadfruit/sweet potato-wheat composite cake. The result of the study showed that fat content increased with an increase in substitution level. The higher fat content of the dry extracted residue cake may be as a result of the processing method which made fat more available.

Carbohydrate content of cakes ranged from $34.90 \%-45.85 \%$ in the raw and $37.14 \%-48.84 \%$ for the dry tiger nut residue flour, with sample E (80\%WF: $20 \% \mathrm{TNRF})$ having the lowest and sample A (100\%WF) as the highest respectively. This result agrees with the findings of Eke-Ejiofor (2013) with a carbohydrate content of 47.76-48.79\% for African breadfruit/sweet potato-wheat composite cake. Carbohydrate content for raw residue in this study (39.66\% to $45.85 \%$ ) is higher than the findings of Algeria-Toran and Farre-Rovira (2003) with a value of $43.30 \%$, but less than the value for dry tiger nut residue cake ( $37.14 \%$ to $41.65 \%)$.

Fibre content ranged from $1.00 \%-3.15 \%$ in the raw and $1.08-2.80 \%$ in the dry tiger nut residue cakes with sample B (95\%WF and 5\% TNRF) and A (100\%WF) as lowest and sample E (80\%WF: 20\%TNRF) as highest, respectively. Eke-Ejiofor (2013) reported a value (1.00 -1.82\%) for African bread fruit/sweet potato-wheat composite cake. Fibre content for raw residue ranging from $1.08 \%$ to $3.15 \%$ and dry residue ranging from $1.08 \%$ to $2.80 \%$ is higher than the findings of Eke-Ejiofor (2013). The result of this study showed that fibre content increased with an increase in the level of substitution. Raw extracted tiger nut residue cake had more fibre when compared with the dry extracted sample. Ash, total available carbohydrate, fat and fiber all increased with an increase in the substitution of tiger nut residue flour with samples showing significant $(\mathrm{p}<0.05)$

\subsection{Proximate Composition of Biscuit from Wheat/Tiger Nut (Raw/Dry) Residue Composite Flour}

Table 2 shows the proximate composition of biscuits from wheat/tiger nut (raw and dry) residue flour. Moisture content of biscuits ranged $1.08 \%-2.78 \%$ for the raw and $1.08 \%-1.85 \%$ for the dry sample Moisture content of the biscuits is lower than the findings of Eke-Ejiofor (2013) with a value of 3.00\%-6.79\% and Olaoye et al. (2007) with a value of $5.19 \%$. The result of this study showed that biscuit from the dry residue flour contained lower moisture content which indicates better storage life and keeping quality of the biscuit. While ash content of the biscuits ranged from $1.34 \%-1.84 \%$ for the raw and $1.35 \%-1.60 \%$ for the dry residue flour with sample A $(100 \% \mathrm{WF})$ as lowest and sample B (95\%WF: 5\%TNRF) as highest respectively. Eke-Ejiofor (2013) reported ash content of $1.05-1.17 \%$ for African bread fruit/sweet potato-wheat composite biscuit samples, which is lower than the result of the present study. Ash content of raw tiger nut residue biscuits (1.35\%to $1.84 \%)$ agrees with the findings of Ayo and Nkana (2003) with a value of $1.82 \%$ and that of dry residue flour ranging from $1.35 \%$ to 
$1.60 \%$ but lower than the findings of Olaoye et al. (2007) with a value of $1.90 \%$. The result of the present study showed that ash content increased with an increase in the level of substitution.

Fat content ranged from $24.89 \%-29.26 \%$ in the raw sample and from $24.89-38.99 \%$ in the dry residue with sample A $(100 \% \mathrm{WF})$ as lowest and sample D (80\%WF: $20 \% \mathrm{TNRF})$ as highest. This result is higher than that reported by Eke-Ejiofor (2013) of $21.93-27.37 \%$. The result showed that fat content increased with an increase in the level of substitution.

Protein content ranged from $7.31 \%-9.46 \%$ in the raw residue biscuit and $8.69 \%-9.56 \%$ in the dry residue biscuit with sample B (95\%WF: 5\%TNRF) as lowest and sample A (100\%WF) as highest. This result is lower than the findings of Olaoye et al. (2007) with a value of $15.83 \%$. Biscuit produced from blends of African bread fruit/sweet potato-wheat composite flour reported a protein content of $5.59-7.08 \%$ which is lower than the present result (Eke-Ejiofor, 2013). Protein content increased with an increase in the substitution of tiger nut residue flour.

Fibre content of biscuits ranged from $1.06 \%-3.13 \%$ in the raw residue sample and from $1.59 \%-3.20 \%$ in the dry residue, with sample A (100\%WF) as lowest and sample D (85\%WF: $15 \%$ TNRF) as highest. Olaoye et al. (2007) reported a value of $0.62 \%$, while Oluwanukomi et al. (2011) reported a value of $0.46 \%$, both of which are lower than the findings of this work. The result of this present study showed that fibre improved when compared with previous works. Fibre content increased with an increase in the substitution of tiger nut residue flour.

Carbohydrate content of biscuit samples ranged from $56.15 \%-69.61 \%$ in the raw residue and from 45.44 $61.63 \%$ in the dry residue product, with sample A (100\%WF) as highest and sample D (85\%WF: $15 \% \mathrm{TNRF})$ as lowest. The result of the biscuit from the raw tiger nut residue ranging from $56.15 \%$ to $61.63 \%$ is higher than the findings of Bamishaiye and Bamishaiye (2011) with a value 54.7\%. While carbohydrate content for dry residue ranging from $45.44 \%-61.63 \%$ is lower than the findings of Eke-Ejiofor (2013) with a value $57.68 \%-65.24 \%$. The result of this present study indicates that carbohydrate content decreased with an increase in the level of inclusion of tiger nut residue flour.

\subsection{Physical Characteristics of Cakes from Wheat/Tiger Nut (Raw and Dry) Residue Composite Flour}

Table 3 shows the volumes and spread ratio of cakes and biscuits produced from raw and dry tiger nut residue flour inclusion up to $20 \%$ and $15 \%$ for cakes and biscuits respectively. Cakes produced from raw and dry residue flour ranged from $598.58-781.46 \mathrm{~cm}^{3}$, and from $598.58-741.84 \mathrm{~cm}^{3}$ in volume with sample A $(100 \% \mathrm{WF})$ as the lowest and $\mathrm{E}(80 \% \mathrm{WF}: 20 \% \mathrm{TNRF})$ as highest in both cases. Cake volume increased with increase in substitution of tiger nut residue flour, and showed a significant difference $(\mathrm{P} \leq 0.05)$ in all its parameters respectively.

While spread ratio of biscuit produced from raw tiger nut residues ranged from 6.72- 9.88, with sample D (85\%WF: $15 \% \mathrm{TNRF}$ ) as lowest and B (95\%WF: $5 \% \mathrm{TNRF}$ ) as the highest. Spread ratio of biscuit produced from dry tiger nut residue ranged from 6.73-7.32 with sample A (100\%WF) as the lowest and D (85\%WF: 15\%TNRF) as the highest. Biscuits showed an increase in spread ratio with an increase in the level off substitution and there was significant difference $(\mathrm{P} \leq 0.05)$ in the entire sample respectively.

\subsection{Sensory Evaluation Result for Cakes Produced from Wheat/Tiger Nut (Raw/Dry) Residue Flour Composite}

Table 4 shows the sensory evaluation result of cakes from wheat/tiger nut (raw/dry) residue flour. Color/appearance for cakes (raw residue) ranged from 3.50-4.55 and 3.7-4.2 for (dry residue) with sample A $(100 \% \mathrm{WF})$ as most preferred and sample E (80\%WF: 20\% TNRF) least preferred in both cases. The decrease in color may be attributed to the creamy color of tiger nut residue flour. Aroma for cakes (raw residue) ranged from 3.45- 4.0 with sample E (80\%WF: $20 \% \mathrm{TNRF})$ as the least preferred and showed no significant difference $(\mathrm{p}>0.05)$ with increase in substitution. While aroma for dry residue cakes ranged from $3.6-3.95$ with all samples very much acceptable. Taste for cake (raw residue) ranged from 3.55 - 4.30 with sample C (90\%WF: 10\%TNRF) as most preferred while taste for cakes (dry residue) ranged from 3.9-4.3 with sample D ( $85 \% \mathrm{WF}$ : $15 \% \mathrm{TNRF}$ ) and $\mathrm{E}$ ( $80 \% \mathrm{WF}: 20 \% \mathrm{TNRF}$ ) as most preferred. General acceptability scores for cake (raw residue) ranged from 3.5-4.15 with sample is showing no significant difference $(\mathrm{p}>0.05)$. While general acceptability scores for dry tiger nut residue cake ranged from 3.9 - 4.25 with sample D (85\%WF: 15\%TNRF) and E (80\%WF: $20 \% \mathrm{TNRF})$ as most preferred. The result for cakes showed significantly difference $(\mathrm{P}<0.05)$ for attribute like color, taste, texture and general acceptability. While aroma showed no significant difference $(\mathrm{P}>0.05)$ for cake samples. Substitution up to $20 \%$ was generally acceptable for cake. 


\subsection{Sensory Evaluation Result for Biscuit Produced from Wheat/Tiger Nut (Raw/Dry) Residue}

Table 5 shows the sensory evaluation result of biscuits from wheat/ tiger nut (raw/dry) residue flour. Color/appearance of biscuits (raw residue) ranged from 3.6-4.15 while (dry residue) ranged from 3.4-4.03. Aroma for biscuit (raw residue) ranged from 3.5-4.0, while biscuit (dry residue) aroma ranged from 3.3-3.65. Taste for biscuit (raw residue) ranged from 3.70-4.15 and biscuit (dry residue) taste ranged from 3.00-4.0. Texture/crispness of biscuit (raw residue) ranged from 3.5-4.3, while texture/crispness for biscuit (dry residue) ranged from 3.20-3.55. General acceptability of biscuit (raw residue) ranged from 3.6-4.35, while that of biscuit from (dry residue) ranged from 3.0-3.95. In all the cases, sample B (95\% WF: 5\% TNRF) was most preferred for the raw extracted residue samples. The result for biscuit showed significant difference $(\mathrm{P}<0.05)$ in all the samples, for attribute like color, aroma, taste, texture and general acceptability. Substitutions up to $15 \%$ were generally acceptable for biscuit.

Table 1. Proximate composition (\%) of wheat/tiger nut (Raw and Dry residue) cake

\begin{tabular}{cccccccc}
\hline \multicolumn{2}{l}{ Sample } & Moisture Content & Ash & Protein & Fat & TAC & Fibre \\
\hline A & a & $21.95^{\mathrm{e}}$ & $0.93^{\mathrm{b}}$ & $10.38^{\mathrm{b}}$ & $18.82^{\mathrm{d}}$ & $45.85^{\mathrm{c}}$ & $1.08^{\mathrm{e}}$ \\
& $\mathrm{b}$ & $21.95^{\mathrm{e}}$ & $0.93^{\mathrm{b}}$ & $10.38^{\mathrm{b}}$ & $18.82^{\mathrm{d}}$ & $45.84^{\mathrm{c}}$ & $1.08^{\mathrm{e}}$ \\
$\mathrm{B}$ & $\mathrm{a}$ & $21.72^{\mathrm{b}}$ & $0.72^{\mathrm{a}}$ & $8.66^{\mathrm{a}}$ & $19.64^{\mathrm{b}}$ & $42.23^{\mathrm{d}}$ & $1.00^{\mathrm{d}}$ \\
& $\mathrm{b}$ & $24.66^{\mathrm{c}}$ & $0.82^{\mathrm{e}}$ & $10.44^{\mathrm{c}}$ & $20.32^{\mathrm{b}}$ & $41.65^{\mathrm{b}}$ & $1.87^{\mathrm{e}}$ \\
$\mathrm{C}$ & $\mathrm{a}$ & $28.05^{\mathrm{c}}$ & $1.29^{\mathrm{b}}$ & $8.53^{\mathrm{d}}$ & $18.81^{\mathrm{c}}$ & $41.01^{\mathrm{b}}$ & $2.22^{\mathrm{b}}$ \\
& $\mathrm{b}$ & $22.87^{\mathrm{b}}$ & $0.93^{\mathrm{b}}$ & $8.81^{\mathrm{d}}$ & $19.87^{\mathrm{c}}$ & $45.11^{\mathrm{c}}$ & $2.41^{\mathrm{c}}$ \\
$\mathrm{D}$ & $\mathrm{a}$ & $26.67^{\mathrm{d}}$ & $1.45^{\mathrm{c}}$ & $10.16^{\mathrm{e}}$ & $19.61^{\mathrm{e}}$ & $39.66^{\mathrm{a}}$ & $2.45^{\mathrm{c}}$ \\
& $\mathrm{b}$ & $22.14^{\mathrm{d}}$ & $1.01^{\mathrm{a}}$ & $8.69^{\mathrm{b}}$ & $17.03^{\mathrm{b}}$ & $49.24^{\mathrm{d}}$ & $2.08^{\mathrm{b}}$ \\
$\mathrm{E}$ & $\mathrm{a}$ & $28.49^{\mathrm{a}}$ & $1.40^{\mathrm{a}}$ & $10.38^{\mathrm{c}}$ & $21.68^{\mathrm{a}}$ & $34.90^{\mathrm{e}}$ & $3.15^{\mathrm{a}}$ \\
& $\mathrm{b}$ & $24.82^{\mathrm{a}}$ & $1.06^{\mathrm{d}}$ & $9.56^{\mathrm{a}}$ & $24.62^{\mathrm{a}}$ & $37.14^{\mathrm{e}}$ & $2.80^{\mathrm{a}}$ \\
\hline
\end{tabular}

Means with different superscript in the same column are significantly different $(\mathrm{P}<0.05)$.

$\mathrm{a}=$ Raw residue

$\mathrm{A}=100 \%$ wheat flour (control)

$\mathrm{C}=90 \%$ wheat flour, $10 \%$ tiger nut residue flour

$\mathrm{E}=80 \%$ wheat flour, $20 \%$ tiger nut residue flour

$\mathrm{TNRF}=$ Tiger nut residue flour $\mathrm{b}=$ Dry residue

$\mathrm{B}=95 \%$ wheat flour, $5 \%$ tiger nut residue flour

$\mathrm{D}=85 \%$ wheat flour, $15 \%$ tiger nut residue flour

$\mathrm{TAC}=$ Total available carbohydrate

Table 2. Proximate composition (\%) of wheat/tiger nut (Raw and Dry Residue) biscuit

\begin{tabular}{cccccccc}
\hline \multicolumn{2}{c}{ Sample } & Moisture content & Ash & Protein & Fat & TAC & Fibre \\
\hline A & $\mathrm{a}$ & $1.08^{\mathrm{d}}$ & $1.35^{\mathrm{b}}$ & $9.46^{\mathrm{b}}$ & $24.89^{\mathrm{d}}$ & $69.61^{\mathrm{b}}$ & $1.06^{\mathrm{d}}$ \\
& $\mathrm{b}$ & $1.08^{\mathrm{d}}$ & $1.35^{\mathrm{b}}$ & $9.46^{\mathrm{b}}$ & $24.89^{\mathrm{d}}$ & $61.63^{\mathrm{a}}$ & $1.59^{\mathrm{d}}$ \\
$\mathrm{B}$ & $\mathrm{a}$ & $2.78^{\mathrm{a}}$ & $1.84^{\mathrm{a}}$ & $7.31^{\mathrm{d}}$ & $26.76^{\mathrm{b}}$ & $61.63^{\mathrm{a}}$ & $2.23^{\mathrm{c}}$ \\
& $\mathrm{b}$ & $1.85^{\mathrm{c}}$ & $1.60^{\mathrm{a}}$ & $8.69^{\mathrm{d}}$ & $35.74^{\mathrm{b}}$ & $47.33^{\mathrm{b}}$ & $1.74^{\mathrm{c}}$ \\
$\mathrm{C}$ & $\mathrm{a}$ & $1.61^{\mathrm{c}}$ & $1.34^{\mathrm{b}}$ & $7.40^{\mathrm{c}}$ & $27.36^{\mathrm{c}}$ & $59.08^{\mathrm{c}}$ & $2.68^{\mathrm{b}}$ \\
& $\mathrm{b}$ & $1.52^{\mathrm{c}}$ & $1.37^{\mathrm{d}}$ & $8.94^{\mathrm{c}}$ & $38.78^{\mathrm{c}}$ & $50.09^{\mathrm{c}}$ & $2.34^{\mathrm{b}}$ \\
$\mathrm{D}$ & $\mathrm{b}$ & $2.10^{\mathrm{b}}$ & $1.57^{\mathrm{b}}$ & $7.79^{\mathrm{a}}$ & $29.26^{\mathrm{a}}$ & $56.15^{\mathrm{d}}$ & $3.13^{\mathrm{a}}$ \\
& $\mathrm{a}$ & $1.39^{\mathrm{d}}$ & $1.42^{\mathrm{b}}$ & $9.56^{\mathrm{b}}$ & $38.99^{\mathrm{a}}$ & $45.44^{\mathrm{d}}$ & $3.20^{\mathrm{a}}$ \\
\hline
\end{tabular}

Means with different superscript in the same column are significantly different $(\mathrm{P}<0.05)$.

$\mathrm{a}=$ Raw residue

$\mathrm{A}=100 \%$ wheat flour (control)

$\mathrm{C}=90 \%$ wheat flour, $10 \%$ tiger nut residue flour

$\mathrm{TAC}=$ Total available carbohydrate $\mathrm{b}=$ Dry residue

$\mathrm{B}=95 \%$ wheat flour, $5 \%$ tiger nut residue flour

$\mathrm{D}=85 \%$ wheat flour, $15 \%$ tiger nut residue flour

$\mathrm{TNRF}=$ Tiger nut residue flour 
Table 3. Physical properties of cakes and biscuits from wheat/tiger nut (raw/dry)residue composite flour

\begin{tabular}{lcccc}
\hline & (Raw residue) & (Dry residue) & (Raw residue) & (Dry residue) \\
\cline { 2 - 5 } Sample & \multicolumn{2}{c}{ Cake } & \multicolumn{2}{c}{ Biscuit } \\
\cline { 2 - 5 } & volume & volume & spread ratio & spread ratio \\
\hline A & 598.58 & $598.58^{\mathrm{d}}$ & $6.73^{\mathrm{c}}$ & $6.73^{\mathrm{b}}$ \\
$\mathrm{B}$ & $741.04^{\mathrm{a}}$ & $652.99^{\mathrm{b}}$ & $6.72^{\mathrm{c}}$ & $7.04^{\mathrm{b}}$ \\
$\mathrm{C}$ & $764.77^{\mathrm{b}}$ & $683.10^{\mathrm{c}}$ & $7.08^{\mathrm{b}}$ & $7.20^{\mathrm{b}}$ \\
$\mathrm{D}$ & $764.14^{\mathrm{a}}$ & $729.65^{\mathrm{a}}$ & $9.88^{\mathrm{a}}$ & $7.32^{\mathrm{a}}$ \\
$\mathrm{E}$ & $781.43^{\mathrm{a}}$ & $741.84^{\mathrm{a}}$ & & \\
\hline
\end{tabular}

Means with different superscript in the same column are significantly different $(\mathrm{P}<0.05)$.

$\mathrm{A}=100 \%$ wheat flour (control)

$\mathrm{C}=90 \%$ wheat flour, $10 \%$ tiger nut residue flour

$\mathrm{E}=80 \%$ wheat flour, $20 \%$ tiger nut residue flour
$\mathrm{B}=95 \%$ wheat flour, $5 \%$ tiger nut residue flour

$\mathrm{D}=85 \%$ wheat flour, $15 \%$ tiger nut residue flour

Table 4. Mean sensory evaluation result of cakes from (raw and dry) Tiger-nut residue composite flour

\begin{tabular}{ccccccc}
\hline \multicolumn{2}{c}{ Sample/code } & Color/Appearance & Aroma & Taste & Texture & General Acceptability \\
\hline A & a & $4.55^{\mathrm{a}}$ & $4.00^{\mathrm{a}}$ & $3.90^{\mathrm{b}}$ & $3.75^{\mathrm{a}}$ & $4.15^{\mathrm{a}}$ \\
& $\mathrm{b}$ & $4.20^{\mathrm{a}}$ & $3.60^{\mathrm{a}}$ & $3.65^{\mathrm{c}}$ & $3.45^{\mathrm{d}}$ & $3.75^{\mathrm{b}}$ \\
$\mathrm{B}$ & $\mathrm{a}$ & $4.25^{\mathrm{b}}$ & $3.65^{\mathrm{a}}$ & $3.90^{\mathrm{b}}$ & $4.00^{\mathrm{a}}$ & $4.05^{\mathrm{a}}$ \\
& $\mathrm{b}$ & $3.70^{\mathrm{b}}$ & $3.55^{\mathrm{a}}$ & $3.45^{\mathrm{c}}$ & $3.65^{\mathrm{c}}$ & $3.65^{\mathrm{b}}$ \\
$\mathrm{C}$ & $\mathrm{a}$ & $3.85^{\mathrm{c}}$ & $3.70^{\mathrm{a}}$ & $4.30^{\mathrm{a}}$ & $3.85^{\mathrm{a}}$ & $4.10^{\mathrm{a}}$ \\
& $\mathrm{b}$ & $3.90^{\mathrm{b}}$ & $3.65^{\mathrm{a}}$ & $3.90^{\mathrm{b}}$ & $3.08^{\mathrm{c}}$ & $3.90^{\mathrm{b}}$ \\
$\mathrm{D}$ & $\mathrm{a}$ & $3.75^{\mathrm{c}}$ & $3.85^{\mathrm{a}}$ & $3.55^{\mathrm{c}}$ & $3.75^{\mathrm{a}}$ & $3.95^{\mathrm{a}}$ \\
& $\mathrm{b}$ & $3.85^{\mathrm{b}}$ & $3.85^{\mathrm{a}}$ & $4.30^{\mathrm{a}}$ & $4.00^{\mathrm{a}}$ & $4.25^{\mathrm{a}}$ \\
$\mathrm{E}$ & $\mathrm{b}$ & $3.50^{\mathrm{b}}$ & $3.45^{\mathrm{b}}$ & $3.60^{\mathrm{c}}$ & $3.45^{\mathrm{b}}$ & $3.50^{\mathrm{b}}$ \\
& $\mathrm{a}$ & $4.30^{\mathrm{a}}$ & $3.95^{\mathrm{a}}$ & $4.20^{\mathrm{a}}$ & $4.05^{\mathrm{a}}$ & $4.30^{\mathrm{a}}$ \\
\hline
\end{tabular}

Means with different superscript in the same column are significantly different $(\mathrm{P}<0.05)$.

$\mathrm{WF}=$ Wheat flour

$\mathrm{a}=$ Raw residue

$\mathrm{A}=100 \%$ wheat flour (control)

$\mathrm{C}=90 \%$ wheat flour, $10 \%$ tiger nut residue flour

$\mathrm{E}=80 \%$ wheat flour, $20 \%$ tiger nut residue flour

$\mathrm{b}=$ Dry residue

$\mathrm{B}=95 \%$ wheat flour, $5 \%$ tiger nut residue flour

$\mathrm{D}=85 \%$ wheat flour, $15 \%$ tiger nut residue flour

$\mathrm{TNRF}=$ Tiger nut residue flour

Table 5. Mean sensory evaluation result of biscuits from (raw and dry) Tiger-nut residue composite flour

\begin{tabular}{|c|c|c|c|c|c|c|}
\hline \multicolumn{2}{|c|}{ Sample } & \multirow{2}{*}{$\frac{\text { Color }}{3.60^{\mathrm{c}}}$} & \multirow{2}{*}{$\frac{\text { Aroma }}{3.25^{\mathrm{c}}}$} & \multirow{2}{*}{$\frac{\text { Taste }}{3.35^{\mathrm{c}}}$} & \multirow{2}{*}{$\frac{\text { Texture }}{3.70^{\mathrm{b}}}$} & \multirow{2}{*}{$\frac{\text { General Acceptability }}{3.60^{\mathrm{c}}}$} \\
\hline A & $\mathrm{a}$ & & & & & \\
\hline & $\mathrm{b}$ & $3.55^{\mathrm{b}}$ & $3.30^{\mathrm{b}}$ & $4.00^{\mathrm{a}}$ & $3.55^{\mathrm{a}}$ & $3.95^{\mathrm{a}}$ \\
\hline \multirow[t]{2}{*}{ B } & $\mathrm{a}$ & $4.15^{\mathrm{a}}$ & $4.00^{\mathrm{a}}$ & $4.15^{\mathrm{a}}$ & $4.30^{\mathrm{a}}$ & $4.35^{\mathrm{a}}$ \\
\hline & $\mathrm{b}$ & $4.05^{\mathrm{a}}$ & $3.30^{\mathrm{b}}$ & $3.05^{\mathrm{b}}$ & $3.25^{\mathrm{b}}$ & $3.25^{\mathrm{b}}$ \\
\hline \multirow[t]{2}{*}{$\mathrm{C}$} & $\mathrm{a}$ & $3.85^{\mathrm{b}}$ & $3.50^{\mathrm{b}}$ & $3.75^{\mathrm{b}}$ & $3.50^{\mathrm{b}}$ & $3.80^{\mathrm{b}}$ \\
\hline & $\mathrm{b}$ & $3.35_{\mathrm{b}}$ & $3.35^{\mathrm{c}}$ & $3.00^{\mathrm{c}}$ & $3.25^{\mathrm{b}}$ & $3.00^{\mathrm{b}}$ \\
\hline \multirow[t]{2}{*}{$\mathrm{D}$} & $\mathrm{a}$ & $3.90^{\mathrm{b}}$ & $3.90^{\mathrm{a}}$ & $3.70^{\mathrm{b}}$ & $3.60^{\mathrm{b}}$ & $3.55^{\mathrm{c}}$ \\
\hline & $\mathrm{b}$ & $3.60^{\mathrm{b}}$ & $3.65^{\mathrm{a}}$ & $3.15^{\mathrm{c}}$ & $3.20^{\mathrm{b}}$ & $3.25^{\mathrm{b}}$ \\
\hline
\end{tabular}

Means with different superscript in the same column are significantly different $(\mathrm{P}<0.05)$. 
$\mathrm{a}=$ Raw residue

$\mathrm{A}=100 \%$ wheat flour (control)

$\mathrm{C}=90 \%$ wheat flour, $10 \%$ tiger nut residue flour

WF: Wheat flour $\mathrm{b}=$ Dry residue

$\mathrm{B}=95 \%$ wheat flour, $5 \%$ tiger nut residue flour

$\mathrm{D}=85 \%$ wheat flour, $15 \%$ tiger nut residue flour

$\mathrm{TNRF}=$ Tiger nut residue flour

\section{Conclusion}

Result from this study has shown the possibility of producing cakes and biscuits of acceptable quality from lesser known and underutilized crop like tiger nut. Cakes and biscuits from tiger nut residue flour composite with wheat were more acceptable nutritionally as they contain significantly more fibre and ash. Wheat flour could be substituted with tiger nut residue flour up to $20 \%$ inclusion level for cakes and $15 \%$ in biscuit without altering the original nature, in terms of color, aroma, taste and texture. The results further showed that in terms of acceptance, the substitution level for biscuit production could depend on the method of processing (raw/dry) the flour. Wheat/tiger nut residue composite cakes and biscuits have proved to be beneficial in term of improved nutrition such as protein, fibre, and ash content of the products. It is therefore a viable substitute for wheat flour since a huge percentage of our foreign reserve is utilized in the importation of wheat. Additionally, tiger nut residue, which is an expected waste, has been turned to wealth and diversification in terms of usage. Products from dry residue flour was more acceptable to the raw residue since products containing raw residue had more moisture content, which has an implication in the shelf life and keeping quality of the end product.

\section{References}

Adejuyitan, J. A. (2011). Tiger nut processing: its food uses and health benefits. AM food Technol, 6(3), $197-201$. http://dx.doi.org/10.3923/ajft.2011.197.201

Ade-Omowaye, B. I. O., Akinwande, B. A., Bolarinwa, I. F., \& Adebiyi, A. O. (2008). Evaluation of tigernut (cyperus esculentus)- Wheat Composite flour and bread. Afr J. Food Sci., 2, 87-91.

AOAC. (1990). Association of Official Analysis chemist (15th Ed.). Washington, DC.

Ajani Alice, O., Oshundahunsi, O. F., Akinoso Rahman, A. K. A., \& Abiodun Aderibigbe, D. (2012). Proximate composition and sensory Qualities of snacks procedure from Breadfruit flour. Global journal of science fronitier Research biological science, 12(7), 1-9.

Akobundu, E. N. T., Ubbaonu, C. N., \& Ndupuh, C. E. (1998). Studies on the baking potential of non-wheat composite flours. J. Food Sci.Tech., 25, 211-214.

Alegria-Toran, A., \& Farre-Rovira, R. (2003). Horchata y salud: Aspectos Nutricionales y dieteticos. In Fundacion. Valenciana da Estudios Avanzados, editor. Jornada chufa y Hotchata: Tradicion y salud. Valencia Spain: Conselleria de Agricultura, Pesca y Alimentacion p.55-70. View at google scholar.

Ayo, J. A., \& Nkana, L. (2003). Effect of acha (D.exilis) flour on the physiochemical and sensory qualities of biscuits. J. of Nutriton and food science, 33(3), 125-130.

Bamishaiye, E. I., \& Bamishaiye, O. M. (2011). Tiger nut: As a plan its derivatives and benefits. Afric J. Food Agric. Nutr. Develop., 11, 5157-5170. http://dx.doi.org/10.4314/ajfand.v11i5.70443

Belewu, M. A., \& Belewu, K. Y. (2007). Comparative physico- chemical evaluation and preparation of tiger nut, soybean and coconut milk sources. Int. J Agric. Biol, 9, 785-787.

Eke-Ejiofor, J. (2013). Proximate and sensory properties of African Breadfruit and sweet potato-Wheat composite flour in Cakes and Biscuits. International Journal of Nutrition and food sciences, 2(5), 232-236. http://dx.doi.org/10.11648/j.ijnfs.20130205.13

Esteshola, E., \& Oreadu, A. C. I. (1996). Fatty acids composition of Tiger nut tubers (cyperusesculentusL.), baobab seeds (Adansoniadigitata L.) and their mixtures. J. American oil chemists society, 73, 255-257. http://dx.doi.org/10.1007/BF02523905

Kure, O. A., Bahago, E. J., \& Daniel, E. A. (1998). Studies on the proximate composition and effect of flour particle size on acceptability of Biscuit produced from blends of Soybeans and plantain flours. Afri J. Food nutrition Devt., 7(1), 1-22.

Magee, E. (2009). Sugar. What kinds to Eat and when. Retrieved July 11, 2009, from WebMD.com (Health and Cooking) 28 January 2009.

Oderinde, R. A., \& Tahir, O. A. (1988). Chemical investigation of Nigerian Cyperus esculentus (L) tuber for possible industrial application. Nig-J. Sci., 22, 70-73. 
Ohl, S. S., Roberta, L. D., \& Hasler, D. (1981). Guide to modern meals (Cakes and frostling) (3rd ed., pp. 466-475). A Webster and McGraw Hill book company.

Oladele, A. K., \& Aina, J. O. (2007). Chemical composition and functional properties of flour produced from two varieties of tiger nut (cyperus esculentus). Afr. J. Biotechnol, 6, 2473-2476.

Olaoye, O. A., Orilude, A. A., \& Idowu, O. A. (2007). Quality characteristics of bread produced from composite flour of wheat, plantain and soybean. Afr. J. Biotechnol., 5(112), 1106.

Oluwanukomi, M. O., Adeyemi, I. A., \& Oluwana, I. B. (2011). Effects of soybean enrichment on the physicochemical and sensory properties of biscuits. Application. Tropical agriculture, 10, 44-49.

Omode, A. A., Fatoki, O. S., \& Olaogun, K. A. (2004). Physicochemical properties of someunderexplioted and nonconventional oil-seeds. Agric food chem., 43, 2850-3. http://dx.doi.org/10.1021/jf00059a015

Oyewole, O. B., Sanni, L. O., \& Ogunjobi, M. A. (1996). Production of Biscuit using cassava flour. Nig. Food, Journal, 3, 24-28.

Osborne, D. R., \& Voogt, P. (1978). The analysis of nutrient in food (p. 240). London, U.K.: Academic press.

Salve, R. V., Mehrajfatema, Z. M., Kadam, M. L., \& More, S. G. (2011). Formulation, Nutritional Evaluation and storage study of supplementary food (Panjiri). J food process Technol., 2, 131.

Victor, C., Ronald, K., \& David, F. (1995). Practical cookery, (cakes, small Cakes, basic mixtures) (8th Ed., pp. 706-707). Euston Road, London: Holder and Stoughlon educational.

\section{Copyrights}

Copyright for this article is retained by the author(s), with first publication rights granted to the journal.

This is an open-access article distributed under the terms and conditions of the Creative Commons Attribution license (http://creativecommons.org/licenses/by/3.0/). 